\title{
Qualia bona in coniuge sunt quaerenda.... Zalecenia na temat wyboru żony w świetle średniowiecznych traktatów o wychowaniu (na przykładzie De regimine principum Idziego Rzymianina)
}

\begin{abstract}
Qualia bona in coniuge sunt quaerenda ... Advice on choosing a wife as reflected in medieval educational treatises (based on De regimine principum by Giles of Rome)

The paper is concerned with the advice regarding choosing a wife presented in the thir-teenthcentury educational treatise De regimine principum by Giles of Rome. It was the most popular "mirror of prince" in the later Middle Ages. In defining the criteria one should pay attention to Giles distinguishes three kinds of "goods" (bona) that an appro-priate wife-to-be should possess. These are the so-called external (exterior) goods and internal (interior) ones, the latter being in turn divided into the bodily goods (bona cor-poris) and the spiritual goods (bona animae). The first kind includes such goods as noble descent (nobilitas generis), multitude of friends (pluralitas amicorum) and abundance of wealth (multitudo divitiarum); the second - beauty (pulchritudo) and size (magnitudo); the third - self control (temperantia) and liking for work (amor operositatis). These three kinds of goods, as well as particular examples of them, are drawn by Giles from Aristotle's Rhetorica. Yet, when compared to those enumerated by medieval theologians and canon lawyers in their discussons of reasons for marrying, they do not considerably differ from them. What matters is that Giles sees and accepts all of them as relatively equally important as criteria used for choosing a wife. This is because they are all neces-sary for setting up a successful marriage that will bring happiness to a man.
\end{abstract}

Keywords: Mirrors of princes, Giles of Rome, education, middle Ages

Śledząc dzieje dawnego piśmiennictwa poświęconego refleksji nad wychowaniem, bez trudu można zauważyć, że znaczące miejsce zajmowała w nim także problematyka małżeńska. Traktowanie w sposób całościowy procesu wychowania jako doprowadzenia i przygotowania do życia dorosłego owocowało nie tylko uwagami na temat poczęcia, opieki nad dzieckiem w pierwszych latach jego życia, a następnie nauczania i wychowania w okresie późniejszym, ale także i pouczeniami stanowiącymi swego rodzaju wychowanie do życia małżeńskiego i rodzinnego. Istotnym elementem tych ostatnich było 
omówienie zasad czy też kryteriów, jakimi należy się kierować, dobierając partnera małżeńskiego ${ }^{1}$.

Zalecenia dotyczące doboru małżeńskiego znajdujemy także w utworach tego gatunku średniowiecznego piśmiennictwa o wychowaniu, jakim były „zwierciadła władców” (specula regum, specula principum). Swymi początkami sięga on czasów antycznych, lecz właściwy rozwój tego gatunku przypada dopiero na wieki średnie, znajdując swoją kontynuację w stuleciach następnej epoki ${ }^{2}$. Na uwagę zasługuje zwłaszcza okres pełnego średniowiecza, który przynosi nie tylko znaczną liczbę spisanych wówczas „zwierciadeł”, ale i żywe zainteresowanie ich autorów problematyką małżeńską ${ }^{3}$. Nie pozostaje ono bez związku z toczącą się w owym czasie intensywną debatą nad instytucją małżeństwa, prowadzoną zarówno na gruncie teologii, jak i prawa kanonicznego ${ }^{4}$. Wkrótce została ona też wzbogacona o nowe treści i problemy przez recepcję pism Arystotelesa, poruszających problematykę małżeństwa ${ }^{5}$. Jednocześnie jest to też czas zainicjowania szerokiego programu działań duszpasterskich, podjętych m.in. przez powstałe wówczas zakony kaznodziejskie, których celem był przekaz także idei i reguł wskazujących, jak żyć w sposób godny i zgodny z chrześcijańskimi zasadami jako mąż i żona. W ramach owej debaty, jak i akcji upowszechniania głoszonych w niej idei, należy zatem sytuować także pouczenia kierowane do panujących.

Jako szczególnie interesujące, m.in. z racji bardzo szerokiego odbioru dzieła, w którym zostały zawarte - o czym szerzej dalej - jawią się zalecenia dotyczące doboru małżeńskiego, jakie przedstawił Idzi Rzymianin (Aegidius Romanus). Ten urodzony około 1243 r. w Rzymie filozof i teolog, uczeń Tomasza z Akwinu, był niezwykle znaczącą postacią ówczesnego świata ludzi kultury uczonej, przez swych współbraci zakonnych obdarzony tytułem Doctor Fundatissimus. Związany był on z zakonem augustianów, do którego wstąpił około 1258 r. W 1292 r. został obrany jego generałem. Około 1295 r. objął urząd arcybiskupa Bourges. Umarł 22 XII 1316 r. w Avignon. Jest autorem licznych

1 Tytułem przykładu, odwołując się tylko do dorobku polskich autorów okresu odrodzenia, można wskazać traktat Erazma Glicznera, Książki o wychowaniu dzieci barzo dobre, pożyteczne i potrzebne ... (1558) czy Mikołaja Reja, Żywot człowieka poczciwego (1568). Odnośnie do epoki średniowiecza zob. S. Vecchio, The Good Wife, w: A History of Women in the West, t. II: Silences of the Middle Ages, red. Ch. Klapisch-Zuber, Cambridge-London 1994, s. 117-118.

2 Na temat „Zwierciadeł” zob. hasło: Fürstenspiegel w: Lexicon des Mittelalters t. 4, München-Zurich 1989, kol. 1040-1052. Ze starszej literatury zob. W. Berges, Die Fürstenspiegel des hohen und späten Mittelalters, Leipzig 1938.

${ }^{3}$ W samym XIII w. oprócz Idziego Rzymianina, autora analizowanego przez mnie zwierciadła, o małżeństwie i relacjach między mężem a żoną, pisali także Wincenty z Beauvais (De eruditione filiorum nobilium) oraz Wilhelm Perald (De erudtione principum).

${ }^{4}$ Zob. np. omówienie, jakie daje N. Cartlidge, Medieval Marriage: Literary Approaches, 1100-1300, Cambridge 1997, s. 12-20 (rozdz.1.2: Medieval Theories of Marriage: Canon Law and Theology). Z prac polskojęzycznych zob. też M. Michalski, Coitus albo consensus, czyli co stanowi o ważności matżeństwa. Relacja z pewnej dyskusji z XI-XIII wieku, w: Nihil superfluum esse. Prace z dziejów średniowiecza ofiarowane Profesor Jadwidze Krzyżaniakowej, Poznań 2000, s. 159-166.

5 Zob. P. Blažek, Die mittelalterliche Rezeption der aristotelischen Philosophie der Ehe. Von Robert Grosseteste bis Bartolomäus von Brügge (1246/1247-1309), Leiden-Boston 2007. 
prac, obejmujących rozległą tematykę, od komentarzy do dzieł Arystotelesa, przez kwestie teologiczne i dzieła egzegetyczne, po traktaty polityczne ${ }^{6}$.

Analizowane w niniejszym tekście ,zwierciadło” jego autorstwa, De regimine principum, powstało około 1280 r. Idzi dedykował je przyszłemu królowi Francji, Filipowi IV Pięknemu. Dzieło to należało niewątpliwie do najbardziej popularnych „zwierciadeł władców" w okresie średniowiecza. Dowodzą tego licznie zachowane rękopisy tego dzieła (sięgające liczby około 350), jak i 24 późnośredniowieczne przekłady i adaptacje na większość ówczesnych języków wernakularnych (m.in. na dawny francuski, włoski, niemiecki, angielski, kataloński, portugalski) ${ }^{7}$. W opinii niemieckiego badacza ,zwierciadeł" Wilhelma Bergesa utwór Idziego był: najbardziej rozpowszechnionym zachodnioeuropejskim zwierciadłem władców $i$ w ogóle najczęściej czytana książka późnego średniowiecza $a^{8}$. Ten stan rzeczy wynikał z tego, że cieszył się on dużą popularnością nie tylko wśród uczonych uniwersyteckich i osób z kręgu monarszego i dworskiego, do którego wszak był bezpośrednio adresowany i którego lekturę im zalecano, lecz także wśród zamożnego mieszczaństwa. Sprzyjała temu dostępność dzieła Idziego zarówno przez jego przekłady na języki wernakularne, jak i formę przekazu, chociaż wciąż zachowującą charakter naukowej rozprawy, ale dostosowaną do odbioru przez „mniej uczonego” czytelnika ${ }^{9}$. Ta popularność czyni też szczególnie pożądanym, z racji tak szerokiego społecznie odbioru, poznanie przekazywanych w nim treści ${ }^{10}$.

De regimine principum to utwór składający się $\mathrm{z}$ trzech ksiąg, $\mathrm{z}$ których każda dzieli się na dalsze części, a te z kolei na poszczególne rozdziały, zawierające szczegółowe rozważania na wyróżnione kwestie związane $\mathrm{z}$ główną tematyką danej części ${ }^{11}$. Przedmiotem naszego zainteresowania jest księga II, w skład której wchodzą trzy części, kolejno omawiające kwestie dotyczące małżeństwa i relacji między mężem a żoną (cz. 1), wychowania dzieci (cz. 2) i zarządu nad służbą i gospodarstwem domowym (cz. 3). Jako całość księga II stanowi traktat poświęcony wspólnocie domowej (domus) ${ }^{12}$. Tym samym

${ }^{6}$ Obszerne omówienie w języku polskim dziejów życia i twórczości Idziego daje M. Olszewski, Idzi Rzymianin, w: Powszechna Encyklopedia Filozofii, t. 4, Lublin 2003, s. 735-741.

${ }^{7}$ Obszernie na ten temat Ch. Briggs, Giles of Rome's De regimine principum. Reading and Writing Politics at Court and University, c. 1275-c.1525, Cambridge 1999, s. 13-20.

${ }^{8}$ W. Berges, op. cit., s. 211 (,,der am weitesten verbreitete abendländische Fürstenspiegel und überhaubt eines der meistgelesenen Bücher des späten Mittelalters”).

${ }^{9}$ Ch. Briggs, op.cit., s. 12.

${ }^{10}$ Należy tu podkreślić wskazywaną przez badaczy pełnioną przez piśmiennictwo dydaktyczne funkcję przekazywania tzw. Orientierungswissen i przez to mogącą bezpośrednio oddziaływać na życie codzienne ludzi. Uzyskujemy w ten sposób pośrednio wgląd w funkcjonujące w wymiarze zbiorowym wyobrażenia ówczesnych ludzi, zob. C. Opitz, Mutterschaft und Vaterschaft im 14. und 15. Jahrhundert, w: Frauengeschichte Geschlechtergeschichte, red. K. Hausen i H. Wunder, Frankfurt - New York 1992, s. 139.

${ }^{11}$ Korzystam z następującego wydania tego dzieła: Aegidii Colvmnae Romani ... De Regimine Principum Lib. III, Romae: Apud Bartholomeum Zannettum 1607 (dalej cyt.: De regimine). Dokonane przekłady fragmentów tego dzieła na język polski są mojego autorstwa.

12 Głównym tematem księgi I jest zachowanie władcy wobec siebie samego , a księgi III - uwagi na temat państwa. Skrótowe omówienie zawartości De regimine dają: Ch. Briggs, op. cit., s. 11-12 oraz P. Blažek, op. cit., s. 167, 172-175. 
ta księga De regimine sytuuje się też w obrębie tego gatunku dawnego piśmiennictwa, jakim były „ekonomiki”, rozwijające się od starożytności po okres wczesnonowożytny ${ }^{13}$.

Interesujące nas zagadnienie wyboru żony Idzi omawia we wskazanej części 1 księgi II, w rozdziałach 12 i 13, w których bezpośrednio przedmiotem szczegółowych rozważań czyni „dobra”, jakie powinna posiadać kandydatka na żonę ${ }^{14}$. Ich przedstawienie warto jednak poprzedzić przybliżeniem zapatrywań Idziego dotyczących roli i znaczenia małżeństwa w życiu człowieka ${ }^{15}$. Kluczowe jest tu stwierdzenie, że człowiek jest z natury istotą małżeńską (homo naturaliter est animal coniugale). Naturalność, jak i znaczenie życia małżeńskiego dla człowieka oparte są na trzech zasadniczych przesłankach ${ }^{16}$. Pierwsza z nich wynika z natury człowieka jako istoty społecznej i wspólnotowej (homo est animal sociale et communicativum), której przeznaczeniem jest życie we wspólnocie. Wspólnoty, w ramach których on żyje to: dom (domus), sąsiedztwo (vicus), miasto (civitas) i państwo (regnum). Jako że spośród nich dla człowieka pierwszą wspólnotą jest wspólnota domowa, stąd człowiek z natury w pierwszej kolejności jest istotą domową (magis est animal domesticum), a dom wspólnotą bardziej dla niego naturalną niż pozostałe. Tym samym też, skoro pierwszą społecznością owego domu jest związek męża i żony, człowiek jest w sposób naturalny istotą bardziej małżeńską niż społeczną ${ }^{17}$.

Druga przesłanka dowodząca, że człowiek z natury jest istotą małżeńską, wynika z naturalnej skłonności człowieka do posiadania potomstwa. Podzielana jest ona przez ludzi z wszystkimi zwierzętami, niemniej u ludzi płodzenie potomstwa ma następować godziwie, w obrębie małżeństwa (debite sit per coniugium). Stąd podyktowane naturą pragnienie posiadania potomstwa czyni w sposób naturalny człowieka istotą małżeńską.

${ }^{13} \mathrm{Na}$ temat piśmiennictwa „ekonomicznego" zob. I. Richarz, Oikos, Haus und Hauhalt. Ursprung und Geschichte der Haushaltsökonomik, Göttingen 1991, o "ekonomice” w dziele Idziego, s. 49-51.

${ }^{14}$ Do wyboru żony pośrednio odnosi się także treść rozdziału 11 (Quod decet omnes ciues \& maxime omnes Reges \& Principes non ducere coniuges sibi nimia consanguinitate coniunctas, s. 250-252), omawiającego przeszkodę małżeńską zbyt bliskiego pokrewieństwa. Przedstawione są tu argumenty przeciw związkom między osobami spokrewnionymi. Zakaz ten ma dotyczyć małżeństw między rodzicami a dziećmi oraz między krewnymi połączonych zbyt bliskim pokrewieństwem (cum consanguineis nimia consanguinitate coniunctis), nie precyzując jednak dokładnie, o jakie stopnie pokrewieństwa chodzi. W czasach współczesnych Idziemu zakaz ten (na mocy postanowień kanonów IV soboru Laterańskiego z 1215 r.) dotyczył osób spokrewnionych w IV stopniu. Odnosił się także do związków powinowactwa i pokrewieństwa duchowego, zob. np. M. Koczerska, Rodzina szlachecka w Polsce późnego średniowiecza, Warszawa 1975, s. 22-23.

15 Temu zagadnieniu poświęcona jest treść rozdziału 7. (Quod homo est naturaliter animal coniugale et quod nolentes nubere non viuunt vt homines, sed vel viuunt vt bestiae, vel viuunt vt dii).

${ }^{16}$ Opiera się tutaj na Etyce nikomachejskiej, ks. VIII.12. Odpowiedni fragment w thumaczeniu polskim brzmi następująco: Między mężem a żona uczucia miłości zdaja się być czymś naturalnym; z natury swej bowiem człowiek jest istota stworzona do życia we dwoje raczej niż do życia w społeczności państwowej-o tyle, o ile dom jest czymś wcześniejszym niż państwo i o ile płodzenie potomstwa jest czymś bardziej wspólnym człowiekowi z innymi istotami żyjacymi. Owóż u innych istot żyjacych wspólżycie zmierza do tego celu tylko, ludzie natomiast mieszkaja razem nie tylko $w$ celu płodzenia dzieci, lecz także dla osiagnięcia różnych celów $w$ życiu; toteż od początku następuje podział prac, i inne należa do męża, a inne do żony; pomagajac więc sobie nawzajem, przyczyniaja się, każde ze swej strony, do wspólnego dobra, cyt. za: Arystoteles, Etyka nikomachejska, tłum. D. Gromska, Warszawa 2007, s. 254.

${ }^{17}$ De regimine, ks. II.1.7, s. 239. 
Podobnie istotą małżeńską czyni człowieka konieczność zapewnienia środków utrzymania, jemu samemu i jego domowi. Prace bowiem wykonywane przez człowieka są różne dla męża i żony. Te przynależne mężowi to działania poza domem (quae sunt fienda extra domum), natomiast te wykonywane przez żonę to czynności wykonywane w domu (intra domum). Służą one wzajemnie mężowi i żonie, jak i ich wspólnocie domowej. Zatem jak wyjaśnia: Skoro czymś naturalnym jest dla czlowieka popęd do zapewnienia sobie środków do życia, naturalnym jest dla niego, że chce być istota matżeńska (Quare si naturale est homini habere impetum ad suffucientiam vitae, naturale est ei, quod velit esse animal coniugale $)^{18}$.

Znaczenie, jakie Idzi przyznaje małżeństwu w życiu człowieka wyraża się również w tym, że jego zdaniem o ile nie istnieją należyte przyczyny, jak oddanie się ,rozważaniom nad prawdą i dziełami Boga" (speculationi ueritatis, \& diuinis operibus), o tyle życie w stanie bezżennym jest życiem istoty nieczłowieczej. Jak wyjaśnia: Albowiem jeśli czymś naturalnym jest dla człowieka być istota matżńska, to ktokolwiek odmawia wziąc sobie żonę, nie żyje jak człowiek. (Nam si naturale est homini esse animal coniugale, quiscunque renuit coniugem ducere, non viuit vt homo). Osąd ten nie dotyczy osoby kierującej się wskazanymi wyżej pobudkami. W stosunku do pozostałych osób jednak Idzi formuje wniosek, że człowiek, który odmawia wzięcia sobie żony, czyni tak, bowiem chce mieć swobodę, aby oddawać się rozpuście (quia uult liberius fornicari) i dlatego wybiera życie „,poniżej człowieka” (infra hominem). Tym samym jest niczym bestia (quasi bestia) ${ }^{19}$.

Biorąc zatem pod uwagę, że poza nielicznymi wyjątkami wszyscy ludzie powinni zawierać małżeństwo, a ich życie upływać we wspólnocie małżeńskiej, to wyjątkowego znaczenia nabiera dobór właściwego partnera małżeńskiego, charakteryzującego się odpowiednimi zaletami. Nie dziwi zatem podjęcie tego zagadnienia przez Idziego i poświęcenie mu obszerniejszego omówienia. Owe zalety w przyjętej przez niego terminologii to dobra (bona), w które powinny „być zdobne” (sint ornatae) żony. Wywód na ich temat konstruuje on, posiłkując się zaczerpniętym od Arystotelesa podziałem. Wyróżnia zatem dobra duszy (bona animae), dobra ciała (bona corporis) oraz dobra zewnętrzne (bona exteriora), przy czym pierwsze dwa rodzaje dóbr łącznie ujęte, składają się na dobra wewnętrzne (bona interiora) ${ }^{20}$.

Wśród dóbr zewnętrznych, powołując się na Arystotelesa (Retoryka, ks. I.5), Idzi wymienia: szlachetność pochodzenia (honorabilitas generis), mnogość przyjaciół (pluralitas

18 Ibidem, s. 239-240.

19 Ibidem, s. 240.

${ }^{20}$ Podziału dóbr na wskazane rodzaje dokonuje zaraz na wstępnie rozdziału 12 (De regimine, ks. II.1.12, s. 253. Odwołuje się w nim wprost do rozdziału 5 księgi I Retoryki Arystotelesa. Odpowiedni fragment w wersji polskojęzycznej brzmi następująco: Dobra wewnętrzne to te, które dotycza duszy i ciała, do dóbr zewnętrznych należa zaś: szlachetne urodzenie, przyjaciele, bogactwo i szacunek, zob. Arystoteles, Retoryka, przełożył, wstępem i komentarzem opatrzył H. Podbielski, w: idem, Dzieła wszystkie, t. 6, Warszawa 2001, s. 318. Podział na dobra „duchowe”, ,cielesne” i ,zewnętrzne” występuje także w Etyce Nikomachejskiej (ks. I.7 Wśród dóbr tedy rozróżniono trzy rodzaje, które nazwano dobrami zewnętrznymi, duchowymi $i$ cielesnymi; cyt. za polskim przekładem, s. 24). 
amicorum) oraz liczne bogactwa (multitudo diuitiarum) ${ }^{21}$. Jakkolwiek należy zważać, aby przyszła żona była ,zdobna” we wszystkie te dobra (sit omnibus his bonis ornata), lecz na uwadze należy mieć przede wszystkim pierwsze dwa. Na majątek, który nabywa się wraz z ręką żony, należy zwracać uwagę jak na coś będącego ich następstwem, jako coś wtórnego wobec nich (quasi ex consequenti). Ostatecznie jednak przy wyborze żony wszystkie te trzy dobra w jakimś stopniu powinny być rozważane (aliquo modo sunt attendenda). Wynika to z tego, że: stuży bowiem matżeństwo do stworzenia stosownej wspólnoty, do zapewnienia życia w pokoju oraz do pozyskania dostatecznych środków do życia (Ordinatur enim coniugium ad debitam societatem, ad pacificum esse et ad sufficientiam vitae). To właśnie owe cele związku małżeńskiego determinują konieczność posiadania wskazanych dóbr przez przyszłą żonę 22 .

One same zresztą są podyktowane także ogólniejszymi przesłankami. Pierwszy z nich wynika z roli związku małżeńskiego w życiu człowieka. Jak już wskazano, Idzi za Arystotelesem przyjmuje, że człowiek z natury jest istotą społeczną, dla którego główna i naturalna społeczność (prima naturalis societas), to związek mężczyzny i kobiety, męża i żony. Jednak ów szczególny charakter społeczności małżeńskiej jest możliwy jedynie wtedy, gdy małżeństwo skutkuje stworzeniem ,społeczności stosownej i naturalnej” (societatem debitam et naturalem). A to z kolei jest możliwe wtedy, gdy dobór współmałżonka następuje stosownie i właściwie (debite et congrue). Oznacza to według Idziego dobór osoby o tym samym pochodzeniu. Stąd, jako że adresatem jego uwag są w tym wypadku królowie i książęta, osoby legitymujące się szlachetnym urodzeniem, wymienia on szlachetność pochodzenia (nobilitas generis) jako dobro, które powinny posiadać ich żony ${ }^{23}$. Wówczas bowiem małżeństwo prowadzić będzie do stworzenia stosownej wspólnoty, w której upłynie ich życie.

$\mathrm{Ku}$ zbudowaniu takiej wspólnoty służą także uwagi Idziego na temat unikania nadmiernej nierówności (nimia imparitas) między partnerami, którego przestrzeganie prowadzi do zachowania godności oraz pokoju w małżeństwie (inter eos sit pax et digna societas). Albowiem jak wyjaśnia:

gdyby wystąpiła nadmierna nierówność, czy to względem pozycji społecznej, czy to względem wieku, byłaby najczęściej przyczyną kłótni albo tego, że małżonkowie sobie wiary nie dochowają. Albowiem jeśli szlachcic poślubi nie-szlachciankę, nie będzie między nimi godziwego towarzystwa, lecz jedno nad drugim będzie chciało dominować, ponad to, co wymagają prawa małżeńskie. Także jeśli zbyt stary poślubi młodą dziewczynę, a ponieważ młodzi nie cieszą się towarzystwem starych, taka nierówność wieku będzie niejaką podnietą, aby małżonkowie wiary sobie nie dochowali.

(Nam imparitas in excessu sive sit secundum nobilitatem sive secundum aetatem ut plurimum est causa litigii vel est causa, ut sibi coniuges fidem non servent. Ut si nobilis nubat ignobili,

\footnotetext{
${ }^{21}$ De regimine, ks.II.1.12, s. 253.

22 Ibidem, s. 253-254.

${ }^{23}$ Ibidem, s. 254.
} 
non erit inter eos digna societas, sed unus alteri ultra quam leges coniugii requirant, dominari cohabitur. Etiam si nimis senes iuvenculae nubat, quia iuvenes societate senum non gaudent, tanta imparitas aetatis erit quoddam incitamentum, ut sibi coniuges fidem non servent $)^{24}$.

Z kolei konieczność zdobycia przez małżeństwo mnogości przyjaciół wynika z usytuowania człowieka w szerszej społeczności ludzkiej, w relacjach z innymi ludźmi i ich charakteru. Porównując organizm człowieka do społeczeństwa, a stan zdrowia do pokoju między ludźmi, Idzi wskazuje, że tak jak nierównowaga między „humorami” prowadzi do słabości i chorób, tak szkody i krzywdy, jakie ludzie sobie wyrządzają, prowadzą do zatargów i wojen. I tak, jak, aby być zdrowym, człowiek musi mieć silną naturę, by pozbyć się tego, co mu szkodzi (habeat naturam fortem, ut nociua expellere), tak, aby żyć w pokoju, potrzebny jest mu dostatek mocy politycznej oraz liczni przyjaciele (abundantia ciuilis potentiae et pluralitas amicorum). W sytuacji zatem, gdy, jak wskazuje, powołując się na Arystotelesa, ludzie chętnie, jeśli mogą, postępują wobec siebie źle, to ten, komu brakuje mocy i nie jest otoczony przez przyjaciół (caret civili potentia et non est munitus amicis), łatwo pada ofiarą niesprawiedliwości i nie jest dane mu życie w pokoju. Do pozyskania przyjaciół z kolei służy małżeństwo. Chodzi tu o krąg przyjaciół i krewnych żony, do którego wejście daje jej poślubienie, i którego rozmiar oraz znaczenie należy zatem mieć na uwadze, dokonując wyboru żony ${ }^{25}$.

Natomiast w odniesieniu do majątku wnoszonego przez żonę Idzi zauważa: poszukuje się bowiem u żon posagów i bogactw dla pokrycia kosztów matżeńskich i z racji pozyskania środków utrzymania życia (Quaerentur enim ex coniuge dotes et divitiae ad supportandum onera matrimonii sive coniugii et propter sufficientiam vitae $)^{26}$. Zauważmy, że w średniowiecznych realiach, zwłaszcza w wypadku wyższych warstw społecznych, spośród której wywodzą się adresaci uwag Idziego, z zawarciem każdego małżeństwa wiązał się nieodłącznie transfer dóbr majątkowych w postaci posagu wnoszonego przez żonę mężowi, stanowiącego formę wydzielenia należnego kobiecie działu majątku rodzinnego ${ }^{27}$. Jest to zatem element doboru małżeńskiego, którego nie sposób wyrugować z dyskusji. Idzi go podejmuje, ale przede wszystkim po to, aby wskazać, jak należy traktować majątek (ostendere, quomodo ex eo quaeri debeat diuitiarum multitudo). Bogactwo powinno pełnić drugorzędną rolę w wyborze żony w stosunku do wskazanych wyżej dóbr $^{28}$. Tę drugorzędność w ocenie Idziego poświadcza również to, że w dokonanym

${ }^{24}$ Ibidem, s. 255. Wymóg równości między małżonkami (ordo aequalis), nie tylko w odniesieniu do stanu i pozycji społeczno-majątkowej, ale i wieku odgrywał bardzo dużą rolę w dyskusji prowadzonej przez średniowiecznych i wczesnonowożytnych autorów na temat doboru i relacji małżeńskich, zob. R. Schnell, Sexualität und Emotionalität in der vormodernen Ehe, Köln - Weimar - Wien 2002, s. 126-131.

${ }^{25}$ De regimine, ks. II.1.12 s. 254.

26 Ibidem, s. 255.

27 Zob. np. M. Koczerska, op. cit.; C. McCarthy, Marriage in Medieval England. Law, Literature and Practice, Woodbridge 2004; K.-H. Spiess, Familie und Verwandschaft im deutschen Hochadel des Spätmittelaters. 13. bis Anfang des 16. Jahrhunderts, Stuttgart 1993.

${ }^{28}$ De regimine, ks.II.1.12, s. 255. 
przez niego podsumowaniu wszystkich dóbr, jakie powinna posiadać odpowiednia kandydatka na żonę, nie wymienia majątku ${ }^{29}$.

W doborze żony także należy zwrócić uwagę na dobra wewnętrzne, na które - jak już wskazano - składają się tak dobra ciała, jak i duszy. Te pierwsze to, jak Idzi podaje, powołując się na Arystotelesa, uroda (pulchritudo) oraz postura ciała (magnitudo). Te drugie to umiarkowanie (temperantia) oraz pracowitość (amor operositatis) ${ }^{30}$.

Jakkolwiek - o czym też dalej - przede wszystkim należy zwracać uwagę na dobra duszy, to zdaniem Idziego - zalety ciała są równie istotne. Nie stanowią one dobra samego w sobie, ale służą realizacji innych celów wyznaczonych instytucji małżeńskiej. Celem małżeństwa są bowiem nie tylko wskazywane zapewnienie godziwego towarzystwa, zachowanie pokoju oraz zapewnienie środków utrzymania, ale także służy ono, nawet bardziej (immo principalis), do należytego spłodzenia potomstwa (ad debitam prolis productionem) i uniknięcia rozpusty (ad fornicationem vitandam). Jak Idzi uzasadnia, dobro zachowania wierności żonie, a będąc wiernym unika się rozpusty, oraz dobro potomstwa są dobrami o wiele bardziej bezpośrednio (magis directe) powiązanymi z małżeństwem. Tego wszystkiego zatem, co działa na rzecz uniknięcia rozpusty, zachowania wierności i godziwego spłodzenia potomstwa należy szukać u żony (Omnia ergo illa, quae videntur facere ad fornicationem vitandam, ad fidem coniugum conseruandam, et ad prolem debite producendam in coniuge quaeri debent $)^{31}$.

Jak zatem wymienione cechy wyglądu zewnętrznego przekładają się na realizację poszczególnych celów małżeństwa? Otóż, jak Idzi wyjaśnia, odpowiednia postura żony przekłada sie na dobro potomstwa $\mathrm{w}$ tym sensie, że synowie z racji tego, że swą materię cielesną posiadają od matek, wielkościa postury ida za matkami (filii in quantitate corporis ut plurimum matrizant). Tak jak u zwierząt, z dużych rodziców rodzą się duzi syno$w^{32}$. Podobnie dobru potomstwa służy kształtność ciała i uroda (formositas et pluchritudo) żony, bowiem z urodziwych rodziców rodzą się urodziwe dzieci (ex pulchris nascuntur pulchri). Jako że godzi się, aby mieć synów urodziwych i odpowiedniej postury, o co troszczyć się powinni wszyscy, a szczególnie królowie i książęta, godzi się też szukać żony urodziwej i słusznej postury. Ponadto uroda u żony przyczynia się także do realizacji drugiego celu małżeństwa, jakim jest uniknięcie rozpusty (sed etiam ad fornicationem vitandam, ad quam vitandam est ipsum coniugium ordinatur $)^{33}$.

Jednak najbardziej istotne zalety żony łączą się przede wszystkim z dobrami duszy, których najbardziej (maxime) należy szukać u żony. Jak Idzi wyraźnie podkreśla: nie wystarczy, że żony będa zasobne w dobra zewnętrzne, czy blyszczaly dobrami ciała, o ile nie znajda się u nich dobra rozumu $i$ duszy (non sufficit affluere bonis exterioribus et pollere corporalibus bonis, nisi adsint ibi bona mentis et animae). Owe dobra wiążą się z niwelowaniem określonych negatywnych cech, jakie Idzi przypisuje kobietom. Pierw-

\footnotetext{
${ }^{29}$ De regimine, ks. II.1.13, s. 258.

30 Ibidem, s. 256.

31 Ibidem, s. 257.

32 Ibidem, s. 257.

33 Ibidem, s. 257.
} 
sze z nich, umiarkowanie, jest pożądane u żony, albowiem kobiety są szczególnie podatne na brak umiaru (ad intemperantiam foeminae maxime incitentur), jak i też dlatego, że umiarkowanie pozwala zapanować nad emocjami, do ulegania którym kobiety również są szczególnie skłonne (moderet passiones, ad quas mulieres incitantur). Podobną funkcję pełni to dobro, jakim jest pracowitość. Jak Idzi wskazuje: albowiem jeśli ktoś jest wolny od zajęcia, jest bardziej skłonny do czynienia tego, co rozum wzbrania (quia cum aliqua persona ociosa existat, levius inclinatur ad ea, quae ratio vetat). Pozostanie bezczynnym, nieoddawanie się dobrym i godnym zajęciom (bonis et licitis exercitis), skutkuje tym, że umysł krąży wokół innych i zajmuje się szpetnymi zamysłami (vagatur circa alias et occupatur cogitationibus turpibus). Dlatego też tak umiarkowanie, jak i pracowitość są tymi zaletami, w które powinny być ,zdobne” kandydatki na żony ${ }^{34}$.

Podsumowując pokrótce wskazane przez Idziego przymioty przyszłej żony, wymienić należy: jako „dobra zewnętrzne” jej szlachetne pochodzenie, pozyskanie przez małżeństwo z nią przyjaciół i znaczenia politycznego oraz majątku, jako „dobra ciała” urodę oraz dorodność i kształtność sylwetki, jako „dobra duszy” umiarkowanie i pracowitość. Zarówno wyróżnione rodzaje dóbr, jak i wybrane ich przykłady zostały zaczerpnięte przez Idziego z pierwszej księgi Retoryki Arystotelesa ${ }^{35}$. Ten jednak owe rodzaje dóbr i ich przykłady wymienia nie w związku z przymiotami żony, lecz z racji definiowania celu wymowy doradczej, którym jest szczęście $i$ wszystko to, co się na nie składa. Wynika to z tego, że, jak Arystoteles wyjaśnia, Szczęście bowiem oraz to, co się z nim wiąże lub jest mu przeciwne, stanowi przedmiot wszelkiej zachęty i odradzania ${ }^{36}$. Idzi posłużył się nimi, aby określić pożądane przymioty przyszłej żony. Wskazane przez niego przymioty-dobra, jakie powinna ona posiadać i które przez związek z nią stają się udziałem męża, to wyróżnione przez Arystotelesa przejawy szczęścia, jego elementy ${ }^{37}$. Małżeństwo jawi się z jednej strony jako środek do jego pozyskania, czy inaczej mówiąc, pozyskania dóbr składających się na szczęście, a z drugiej - jako stan posiadania owych dóbr, to jest szczęście. Można zatem się dopatrywać w zaproponowanym przez Idziego wykazie przymiotów żony swoistej recepty na szczęśliwy związek małżeński.

Odwołanie się przez Idziego do pism Arystotelesa w celu nakreślenia zaleceń dotyczących doboru żony stanowi novum w stosunku do praktyki jego poprzedników, auto-

34 Ibidem, s. 258.

35 Zaczerpnięte zostały z rozdziału 5 księgi I Retoryki. Odpowiedni fragment w wersji polskojęzycznej brzmi następująco: Dobra wewnętrzne to te, które dotycza duszy i ciała, do dóbr zewnętrznych należa zaś: szlachetne urodzenie, przyjaciele, bogactwo i szacunek [...] Zalete ciała dziewczat stanowi uroda i odpowiedni wzrost, duszy - umiarkowanie i pracowitość, ale nie niewolnicza, zob. Arystoteles, Retoryka, s. 318-319.

36 Ibidem, s. 318

${ }^{37}$ Ibidem: Szczęście jest to pomyślność związana z dzielnościa lub niezależność, lub życie bezpieczne i petne przyjemności, lub téz bogactwo i dobre zdrowie oraz zapewniona możliwość korzystania z nich. Niemal wszyscy zgodza się chyba, że szczęściem jest jedna lub kilka z wymienionych rzeczy. Jeśli taka jest istota szczęścia, to jego przejawami muszą oczywiście być: szlachetne urodzenie, posiadanie wielu i uczciwych przyjaciót, bogactwo, dorodne i liczne potomstwo, piękna starość, takie zalety ciała jak: zdrowie, uroda, siła, odpowiedni wzrost, uzdolnienia sportowe; ponadto dobre imię, szacunek, sprzyjający los, dzielność (lub jej składniki: madrość, męstwo, sprawiedliwość i umiarkowanie). 
rów zwierciadeł władców, również omawiających ten problem ${ }^{38}$. Jest to poniekąd zrozumiałe, zważywszy stosunkowo niedawną recepcję pism Stagiryty, chodzi tu przede wszystkim o dzieła z zakresu filozofii praktycznej, przypadającą na czasy zaledwie na jedno pokolenie wcześniejsze. Niemniej - jak już wspomniano - sam temat i zainteresowanie nim nie są nowe. Był on przedmiotem szerokiej dyskusji obecnej w średniowiecznym piśmiennictwie w ramach rozważań teologiczno-filozoficznych, jak i dyskursu prowadzonego na gruncie prawa kanonicznego na temat instytucji małżeństwa. W odniesieniu do doboru małżeńskiego, autorzy poruszający tę kwestię mogli się oprzeć na wypracowanej przez Augustyna koncepcji trzech dóbr małżeństwa: potomstwa, wierności i nierozerwalności (proles, fides, sacramentum) oraz uwagach dotyczących motywów (causae) jego zawierania. Wśród nich dokonywano rozróżnienia na przyczyny pierwszorzędne (causae primae), jak spłodzenie potomstwa (causa prolis) i uniknięcie nierządu (causa incontinentiae, vitatio fornicationis), oraz przyczyny drugorzędne (causae secundae), jak pozyskanie przyjaźni (acquisitio amicitiae), przywrócenie pokoju (reformatio pacis), uroda żony (pulchritudo uxoris) czy też majątek (divitiae). Wśród tych drugich dodatkowo rozróżniano przyczyny szlachetne (honestae causae), obejmujące dwa pierwsze i mniej szlachetne (minus honestae), obejmujące dwa pozostałe. Miejsce pośrednie, niekiedy będąc jednak dołączana do przyczyn pierwszorzędnych, zajmowała ta przyczyna, jaką było wzajemne wsparcie udzielane sobie przez małżonków (adiutorium). W ramach tych rozważań wskazywano również na takie przymioty żony, jak: pochodzenie (gens), uroda (pulchritudo), bogactwo (divitiae) i szczególnie zalecana obyczajność (mores) ${ }^{39}$.

Gdy zatem porównamy wymienione motywy z dobrami i celami małżeństwa wskazanymi przez Idziego, to pod względem rzeczowym nie widać pomiędzy nimi istotnej różnicy. Ta odnosi się przede wszystkim do przyjętej hierarchii ważności między nimi i sposobu ich wartościowania. Na przykład, uroda żony wymieniana przez teologów i prawników jako motyw drugorzędny i mniej szlachetny zyskuje u Idziego na znaczeniu i znajduje uzasadnienie jako czynnik odgrywający kluczową rolę w realizacji celów małżeństwa wymienianych jako pierwszorzędne, to jest spłodzeniu potomstwa i uniknięcie nierządu poprzez zachowanie tego dobra małżeństwa, jakim jest wierność. Także dobra materialne pozyskiwane wraz z ręką żony, jakkolwiek nie powinny odgrywać decydującej roli w doborze małżeńskim, niemniej również stanowią nieodłączny element namysłu nad doborem żony, służą bowiem do zapewnienia środków utrzymania wspólnocie domowej. W ówczesnych realiach społecznych istotny był wkład obu stron w stworzenie podwalin pod nowe gospodarstwo domowe. Atrakcyjność fizyczna żony, jak i wnoszony przez nią w posagu majątek, w ocenie teologów i prawników drugorzędne i wymieniane przede wszystkim jako przykłady obecnych w praktyce społecznej motywów, a nie zale-

${ }^{38}$ Zob. P. Bläzek, op. cit., s. 167. Przykładem mogą być pouczenia zawarte w De regimine filiorum nobilium autorstwa Wincentego z Beauvais, odwołującego się do tradycji biblijnej i patrystycznej; w polskiej historiografii ich omówienie daje A. Fijałkowski, Puer eruditus. Idee edukacyjne Wincentego z Beauvais (ok. 11941264), Warszawa 2001, s. 156-159.

39 R. Weigang, Liebe und Ehe im Mittelalter, Goldbach 1998, s. 3-36; R. Schnell, op. cit., s. 228-231; G. Signori, Von der Paradiesehe zur Gütergemeinschaft. Die Ehe in der mittelalterlichen Lebens- und Vorstellungswelt, Frankfurt - New York 2011, s. 13-31. 
cenia, u Idziego zyskują akceptację i wskazanie jako przedmiot namysłu i rozwagi. Mogło to być wynikiem wpływu Arystotelesa, według którego warunkiem pełni szczęścia jest względny całokształt różnych kategorii dóbr, tak wewnętrznych, jak i zewnętrznych. Bowiem, jak to ujmował: Całkowita niezależność, która jest jednym ze sposobów określenia szczęścia, może więc osiagnąć ten, kto posiada jednocześnie dobra zewnętrzne $i$ wewnętrzne $e^{40}$.

Zauważmy również, że u Idziego owe dobra, w które powinny być ,zdobne” kandydatki na żonę, nie stanowią wartości samej w sobie. Raczej wynikają one oraz służą, czy nawet są podporządkowane (ordinantur) małżeństwu, którego zawarcie również nie tyle jest celem samym w sobie, lecz środkiem do jego osiągania. Celem tym zaś, zgodnie z tym, co już wskazano, jest szczęście - szczęście, jakie człowiek może osiągnąć w ramach życia społecznego. W ówczesnej praktyce społecznej warunkiem zapewnienia genealogicznej kontynuacji rodziny jest nie tylko spłodzenie męskiego potomstwa, ale i jego zrodzenie w prawowitym związku, które uprawniało do dziedziczenia rodzinnego majątku. Pozycję człowieka w hierarchii społecznej w decydującej mierze określał posiadany majątek, którego pozyskaniu służyło także małżeństwo, którego zawarcie dla kobiety oznaczało zgodnie z ówczesnym prawem wydzielenie jej jako posagu należnej części majątku rodzinnego, a dla męża - wniesienie tych zasobów do jego rodziny. Zawarcie małżeństwa skutkowało nie tylko powstaniem nowej relacji (związku) między dwiema osobami, żoną i mężem, ale i powstaniem powiązań wśród zdecydowanie szerszej grupy osób. Chodzi tu o odgrywające dużą rolę w dawnych realiach społecznych związki wynikające z powinowactwa, w pierwszej kolejności, a następnie, po zrodzeniu potomstwa, z pokrewieństwa po kądzieli, pociągające za sobą zobowiązane do pomocy i protekcji, przynajmniej na płaszczyźnie oczekiwań i przymusu etycznego, co ich udzielania. Z kolei dla praktycznego wymiaru pożycia małżeńskiego, bezpośrednich relacji między mężem a żoną, nie bez znaczenia były również przymioty jej charakteru (jak i charakteru mę$\dot{z} a)^{41}$. Usytuowanie człowieka jako istoty z natury społecznej w szerszej, jak i węższej (dom) wspólnocie stawiało przed nim różnorodne zadania, do których szczęśliwej, wieńczonej powodzeniem realizacji mogło skutecznie przyczyniać się zawarte przezeń małżeństwo. Związek małżeński, aby mógł być źródłem szczęścia, musiał opierać się na szerokiej podstawie dóbr, jakie do niego wnosiła żona, w czym upewniała Idziego nie tylko lektura pism Stagiryty, ale i zapewne uważna obserwacja życia społecznego.

\footnotetext{
${ }^{40}$ Cyt. za: polskim thumaczeniem Arystoteles, Retoryka, s. 318.

${ }^{41} \mathrm{Na}$ temat uwarunkowań i motywów doboru małżeńskiego w praktyce społecznej zob. np. moje wnioski sformułowane na przykładzie praktyki późnośredniowiecznego możnowładztwa wielkopolskiego, W. Brzeziński. Koligacje matżeńskie możnowładztwa wielkopolskiego $w$ drugiej połowie XIV i pierwszej połowie XV wie$k u$, Wrocław 2012, s. 296-315.
} 